\title{
COMPREHENSIVE INCOME IN EUROPE: VALUATION, PREDICTION AND CONSERVATIVE ISSUES
}

\author{
Assistant Professor PhD Igor Goncharov, University of Amsterdam, The Netherlands, \\ e-mail: i.goncharov@uva.nl \\ Professor PhD Allan Hodgson, University of Amsterdam, The Netherlands, \\ e-mail: A.C.Hodgson@uva.nl
}

ABSTRACT: The IASB comprehensive income project extends the 'fair value' measurement concept from the balance sheet into the income statement. This article extends prior research, primarily based on Anglo-Saxon countries, by using a comprehensive data set of 56,700 European firm years over sixteen countries. We find that other comprehensive income provides incremental information to investors - due to unrealised available-for-sale securities component - and affects analysts' decision to revise price estimates. On the other hand, traditional operating net income dominates aggregated comprehensive income as a valuation metric and in predicting cash flows. Results are robust to pooled and country specific regressions, controls for non-linearities, impact of reporting incentives, and the underlying accounting framework (local GAAP, US GAAP, IFRS). We also find that aggregated comprehensive income switches the conservative attributes of income towards a more timely recognition of good news over bad news, reducing the conservative agency contracting role. One possible explanation is the mixing of different concepts of operating capital increments with unrealised gains and realised historic net income. An agenda item for the IASB is how income reporting should be disaggregated with a clear delineation on capital increments, conservative operating income, and unrealised financial gains. This is especially important in Continental Europe which relies to a greater extent on debt capital and has an under-developed corpus of equity financial analysts.

Keywords: comprehensive income, value relevance, analyst forecast revisions, European IFRS, accounting conservatism

JEL Codes: M41, G12

We appreciate the useful comments of Ray Ball, Begonia Giner, Bill Rees, Ann Tarca, and the participants of the EAA 2007 in Lisbon.

\section{Introduction}

A significant change in European accounting was induced by the mandatory application of international financial reporting standards (IFRS) for listed firms in the European Union (EU) from 2005. Underlying IFRS is a conceptual shift towards timely recognition of price changes and the adoption of the 'fair value' approach as a working principle. These concepts derive from AngloSaxon practices built up from common law precepts with an investor/decision making focus.

Before the introduction of IFRS accounting standards were the responsibility of individual European member states. European Directives provided the framework but every country had its own rules; in some drawn up by professional bodies, in others by government bodies. However, an over-riding and prevalent driver was the strong link to taxation and debt (Nobes and Parker 2004). That is, a stewardship/debtholder focus structured on conservative principles, banking covenants, 
and taxation. Hence, IFRS abruptly created a conceptual gap between pre-2005 and current financial reporting practices in Europe. ${ }^{1}$

Moreover, the International Accounting Standards Board (IASB) is currently involved in a project on reporting comprehensive income (Performance Reporting), that promises to widen this gap even further. First, income will conceptually include all relevant events (including price restatements) and transactions during the period and be reported in a comprehensive income statement. Separate statements of unrealised gains and losses that allow flexibility in reporting fair value changes as profits or dirty surplus reserve adjustments (as in the UK or SFAS 130 in the US) will not be allowed. Second, it is still to be decided whether price restatements are to be embedded into operating and finance components of income or reported separately as other comprehensive income.

Whether income should be reported on a comprehensive clean surplus basis, or based on net income from core operations with non-operating (dirty surplus flows) accounted for directly in reserves, has been an ongoing and ambivalent issue over the last seven decades (see Paton 1934; Dhaliwal et al. 1999; O'Hanlon and Pope 1999; Cahan et al. 2000; Hirst and Hopkins 1998; Johnson et al. 1995; May 1937). The issue also has been controversial in a political sense with the Accounting Standard Setting Board of Japan initially requesting the project be stopped and the European Financial Reporting Action Group (EFRAG) formed to make a pro-active contribution to the work of the IASB. ${ }^{2}$ Disagreement relates to whether departure from clean surplus, recycling of dirty surplus items, the (non)inclusion or transitory elements, and the reporting location, represents reduced or increased transparency for decision making.

This paper re-examines the issue using a broad dataset of European countries that cover a wider conceptual context, thereby extending prior research that focuseson Anglo-Saxon countries. Specifically the data contains sixteen European countries (14 from Continental Europe) over the period 1991 to 2005 and provides 57,000 firm-year observations. ${ }^{3}$ There are several reasons that motivate our research. First, changing the focus of income determination to include unrealised fair value changes potentially could have a far greater impact on European code law countries compared to Anglo-Saxon countries that are more focused on equity holders as primary users. ${ }^{4}$ Second, the concept of value relevance is unclear (Van Cauwenberge and De Beelde 2007a). Prior studies almost exclusively link value relevance to incremental information and apply a price revision model, possibly due to research focussed on well developed capital markets with an assumption of relative information efficiency. We add to this approach by using accounting numbers as measurements that are descriptive of fundamental value. ${ }^{5}$ A measurement approach may be more

\footnotetext{
${ }^{1}$ The shift has been partially motivated by research reporting low (or declining) value relevance of traditional rule based accounting (Francis and Schipper 1999; Lev 1989), and a pre-eminent objective function for the provision of information that enables the efficient allocation of capital (Cornell and Landsman 2006, p.34). Whether increased fair value measurement techniques provide opportunities to convey private information or increase opportunistic behavior is an open question (Hung 2001). Barth et al. (1996) argue that increasing the extent of accrual accounting facilitates better matching and improved value relevance of earnings, whilst Ball et al. (2003) believe just imposing standards that allow greater flexibility with reduced conservatism will not improve value relevance.

2 EFRAG plans to be influential at an early stage by commenting on revenue recognition, which they believe has now become a critical issue because of the approach taken by the IASB and Financial Accounting Standards Board (FASB) in linking revenue recognition to the definition of assets and liabilities. EFRAG has also echoed concerns of financial statement preparers about the obligation to provide reliable data and the duty of auditors to attest the data.

${ }^{3}$ To our knowledge, this data represents the widest ranging study of European countries. A comparative study is Isidro et al. $(2004,2006)$ which is limited to 2,410 firm years derived from the US, UK, France and Germany.

${ }^{4}$ We later report a median relative importance of comprehensive income components of between 15.1 and 40.1 percent and an increasing trend over time (see Table 2).

${ }^{5}$ Derived from (say) a theoretical model such as Ohlson (1995).
} 
relevant for continental European firms who operate in less developed secondary stock markets and is more in line with the qualitative relevance objectives of standard setters. ${ }^{6}$

Third, we supplement the analysis of stock price value relevance by testing predictability for cash flows and impact on financial analyst forecasts of prices. Cash flows because they are not based on presumptions of market efficiency and provide fundamental information on the financial solvency of the firm. Analyst price revisions because they provide a specialised test (Francis and Willis 2001; McNichols and O'Brien 1997). In short, they follow firms with a high level of imbedded asymmetric information (Matolcsy and Wyatt 2006), and if comprehensive income accounting adjustments contain asymmetric information, we should observe a correlation with price revisions.

Fourth, we add a modelling refinement. Previous research assumes a linear relationship but this approach takes no account of the higher level of temporary components in the comprehensive income measure. This causes obvious difficulties in comparing regression coefficients and hence the comprehensive income functional relation may be misspecified and cause misinterpretations. The possibility of non-linearity is addressed by estimating arctan models that account for these temporary components.

Finally, the concept of value relevance is interpreted mainly from an incremental information based perspective for equity investors, with studies ignoring other providers of capital. This contrasts with the statements of the IASB and FASB who define usefulness in a wider context that includes equity investors, lenders and other creditors. Consistent with the proposition of Watts (2003) and Ball et al. (2003), that conservative financial accounting enables the formation of contacts reduce agency costs, we extend Biddle and Choi (2006) by examining conditional conservatism aspects.

Briefly, we find that net income dominates aggregated comprehensive income as a decision relevant metric for stock prices from a measurement perspective, an information perspective, and for predicting cash flows. Results are robust to controls for non-linearities, time effects, individual country regressions and the underlying type of accounting framework. However, the incremental component of comprehensive income, over and above net income, is found to have significant value relevance and this is driven by unrealised gains and losses on held-for-sale securities. We also find that other comprehensive income provides information to analysts in revising price forecasts, and aggregated comprehensive income performs equally well to net income in explaining analyst behaviour. Finally, comprehensive income incorporates good news in a more timely fashion than bad news and this reduces the conservative aspects of net income.

The paper now proceeds as follows. The next section provides a background overview, section three describes the data, and section four outlines the empirical models. Section five reports the empirical results using pooled data and section six the results using individual countries and decompositions based on the individual countries and underlying accounting systems. The paper is concluded with a summary and discussion in section seven.

\section{Background}

\section{Overview}

In IASB Discussion Paper (DP)- Preliminary Views on Financial Statement Presentation (2008) comprehensive income includes both realised and unrealised changes in fair values and includes net income as one component of comprehensive income. Other comprehensive income components may include such items as unrealized gains and losses on financial investments and

\footnotetext{
6 Van Cauwenberge and de Beelde (2007a) argue that value relevance studies under the information perspective are inferior vis-a-vis valuation based association studies.

${ }^{7}$ We note that analysts are not as active in Continental Europe in disseminating information. Only about four percent of our collected firm years have analyst following.
} 
non-current assets, changes in foreign currency translation reserves, changes in pension reserves, extraordinary items, and sundry reserve adjustment items. Except for foreign translation adjustments, all components should be identified with operating, investing or financing categories.

Under FASB SFAS 130 (1997) firms could report comprehensive income either as part of the income statement or as a statement of changes in equity, but the recent IASB DP development suggests a number departures. If accepted, comprehensive components will no longer be allowed to be reported in an equity statement with a single all-inclusive comprehensive income replacing previous alternate presentations. Further, profit and revenue recognition will be more strongly linked to timely price recognition and the fair value approach. Thus, unrealized gains and losses on available-for-sale marketable securities as well as gains and losses on plant and equipment and other operating assets will be included as income; and re-measurements will comprise a much larger proportion of income.

Whilst, comprehensive income represents an aggregated approach to income determination, disaggregation into separate components will be allowed '...to the extent that it will enhance usefulness in predicting the entities future cash flows.' (IASB ED 2008, 3.42) Reflecting a major objective of the IASB for financial statements to assist decision making by enhancing predictions of future performance. A stance supported by a number of proponents based on the presumption that comprehensive income better measures firm performance because it includes all changes in the net assets of a firm during the reporting period: “...an analyst's forecast can be used to value stock only if it is a forecast of comprehensive income, and a price/earnings ratio only has a precise interpretation if the earnings are comprehensive..." (American Accounting Association's Financial Accounting Standards Committee 1997). That is, it captures all sources of value creation and forces managers to consider external factors that affect firm value, not just internal operating ones.

Conceptually, comprehensive income is consistent with the clean surplus income theory of Ohlson (1999). A departure from clean surplus accounting means some value changes are booked direct to equity with a perceived lack of transparency (Smith and Reither 1996). Another issue is the process of recycling where dirty surplus flows, initially booked to equity, are after realization are subsequently rebooked to equity through the income statement. It is argued the immediate recognition and direct reporting of these components in comprehensive income would transparently present all income flows in one statement in a timely manner and avert the possibility that users may double-count (Association for Investment Management and Research (AIMR) 1993). On the other hand, others retort that comprehensive income contains a number of transitory components contingent on future events. This introduces noise and uncertainty and inhibits decision making because users may take significant time to sift out temporary or irrelevant components (Brief and Peasnell 1996; Tarca 2006). A similar line of reasoning goes further by proposing that comprehensive income includes extraneous components that reduce the ability to uncover long-run performance (Stark 1997; O'Hanlon and Pope 1999).

\section{Value relevance studies}

Much of the prior research has concentrated on the incremental information content (defined as impact on stock price changes) of the components of comprehensive income over net income for shareholders. Results are mixed. Cheng et al. (1993) (US) and Brimble and Hodgson (2005) (Australia) report net income has higher value relevance than comprehensive income, O'Hanlon and Pope (1999) (UK), Cahan et al. (2000) (NZ) and Isidro et al. (2006) (France, Germany, UK, US) report no incremental information content for comprehensive income components, whilst Dhaliwal et al. (1999) (US) and Biddle and Choi (2006) (US) and Kubota et al. (2006) (Japan) report that comprehensive income has a higher association with stock returns. The more consistent result is the unrealized gain or loss on securities held-for-sale or short term financial investments has a significant association with price changes or abnormal returns (for example see Barth and Clinch (1998), Kanagaretnam et al. (2006), and Chambers et al. (2007). 


\section{Reporting location and aggregation}

In the past other comprehensive income was reported in the footnotes (if at all) or in a statement of changes in equity, whereas the recent move of IASB requires reporting a single aggregated comprehensive income figure. The question then is whether aggregation and reporting location matter? If security markets are information efficient then these issues are of no importance. But if markets have semi-strong form inefficiencies and are influenced by psychological factors, reporting and disclosure issues do influence investor decisions.

For example, location strengthens perceptions of importance. If individual investors perceive information to have a stamp of importance (such as being included as income) then they weigh this information more heavily in their decision making (Sanbonmatsu et al. 1997; Maines and McDaniel 2000). On the other hand, location may also reveal incremental information. According to Hirst and Hopkins (1998) the form of disclosure of comprehensive income and components assists analysts in detecting earnings management. Lee et al. (2006) also show that insurance firms who manage earnings through realised security gains (and have a reputation for poor financial performance) are more likely to report comprehensive income components in the statement of changes in equity. But, Chambers et al. (2007) show limited evidence of incremental information when the comprehensive income components are reported through an income statement and higher information content when reported in the changes in equity. Chambers et al. (2007) argue this explains why the majority of firms choose to disclose through the changes in equity statement.

Aggregation issues also permeate the above discussion and according to Libby et al. (2002) and similar to Imhoff et al. (1995) physical, knowledge and cognitive issues cause investors to stray from rational decision models and rely on simple heuristics. Therefore, aggregations become more important rather than a full examination of (perceived) complex accounting reports. The extensive use of $\mathrm{P} / \mathrm{E}, \mathrm{PEG}$ and earnings per share for valuation purposes provides a widespread example of this phenomenon. To summarise, in incomplete markets, reporting location and form can substantially influence decision making.

\section{Income as an agency contract}

Holthausen and Watts (2001) question the acceptance of value relevance for potential and current shareholders as the sole criterion for calculating income. Another approach is to assess the impact of comprehensive income measures on contracting behaviour by noting that another demand for accounting originates in the agency markets. For example, Jensen and Meckling (1976) and Watts (1977) argue the purpose of financial reporting is to reduce agency costs of both investors and debtholders, and a number of empirical studies show a link between the properties of accounting numbers and contractual settings. Healy (1985), for example, relates companies' accrual choices with the terms in bonus contracts, and the results in Basu (1997) are consistent with litigation costs explaining a pattern of increases in conservative accounting practices over time. Ball et al. (2008) links cross-sectional differences in the extent of conditional conservatism (and the timeliness of bad news) to the demand of debtholders.

This extension is also consistent with the IASB and FASB who recently defined usefulness in a wider context that includes equity investors, lenders and other creditors, as well as managerial contract arrangements. Moreover, it is also consistent with common law accounting practiced widely in Continental Europe pre-2005 with a stewardship/debtholder focus structured on conservative principles, banking covenants, and a strong tax influence. Therefore, if comprehensive income can increase the efficiency of (debt) contracting then the implications of the previous (value relevance) studies can be extended.

Biddle and Choi (2006) propose that differential measures of income are more decision relevant for valuation and contract applications. They find that comprehensive income as defined by SFAS 130 is the dominant income metric for explaining equity returns. However, for chief executive compensation evaluation, net income dominates and none of the comprehensive income 
components are significant. If these results are generally descriptive of the real world then accounting bodies should provide different income models - one appropriate for valuation and one appropriate for contracting. ${ }^{8}$

\section{Overview}

Prior comprehensive income studies narrowly interpret value relevance from a shareholder perspective and consider incremental changes in share prices in their tests. Empirical results for comprehensive income are mixed but a number show significant value relevance for adjustments to financial assets held-for-sale. Behavioural based research suggests that the issue of where we report and aggregate income is an important consideration and to date no account has been made for modelling the non-linear impact of the higher level of transient components in comprehensive income. Moreover, other providers of capital and the role of financial accounting as a contracting or stewardship are generally ignored.

We argue the components of comprehensive income differ between countries and over time (primarily due to reporting incentives but also accounting standards) and that earnings quality differs between countries as documented by Ball et al. (2000) and Burgstahler et al. (2006). Further, some countries rely to a greater extent on non-accounting information. One limitation we see with previous studies is they are based on Anglo-Saxon accounting systems with developed stock markets and examine a single or a few countries. The main contribution of this paper is to extend the analysis across European countries, with fourteen embedded in the Continental code law system that was reliant on diffused capital contributors. In summary, we undertake a substantial comparative cross-country study that considers a wider range of research issues.

\section{Data, income measures and descriptive statistics}

Data on European listed companies was obtained by accessing accounting data from Worldscope, firm-specific market data from Datastream, and information on analysts' forecasts from I/B/E/S. The sample consists of sixteen countries: Austria, Belgium, Denmark, Finland, France, Germany, Greece, Ireland, Italy, Netherlands, Norway, Portugal, Spain, Sweden, Switzerland and United Kingdom. Firm-years with missing accounting or market data and firms in financial distress, signalled by a negative value of stockholders equity, were excluded. Retained firms require financial information for at least three years to ensure the calculation of all variables. Noting that most countries have a limited number of firm-year observations before 1990, we concentrate on a sample that spans the years 1991 to 2005 (lagged data from 1990 is used for scaling). Finally before performing each test, we drop observations of the main test variables in the 1 st and the 99 th percentiles to control for outliers. We utilise: 56,702 firm-year observations in the conservatism tests, 56,696 observations in the value relevance analyses, ${ }^{9} 29,489$ in the prediction of future cash flows, and 2,368 for the analyst forecast revision tests. Table 1 reports descriptive statistics for the sample used in the value relevance analysis.

\footnotetext{
${ }^{8}$ See also Van Cauwenberge and De Beelde (2007b) who propose dual income reporting.

${ }^{9}$ The number of observations in value relevance and conservatism analysis differs slightly because of the different definition of the return window.
} 
Table no. 1

Descriptive Statistics

\begin{tabular}{|c|c|c|c|c|c|}
\hline Country & $\mathrm{N}$ & Country & $\mathrm{N}$ & Country & $\mathrm{N}$ \\
\hline Austria (AU) & 975 & Greece (GR) & 1,921 & Spain (ES) & 1,678 \\
\hline Belgium (BE) & 1,403 & Ireland (IR) & 745 & Sweden (SW) & 2,423 \\
\hline Denmark (DK) & 2,251 & Italy (IT) & 2,549 & Switzerland $(\mathrm{CH})$ & 2,578 \\
\hline Finland (FI) & 1,167 & Netherlands (NL) & 2,187 & \multirow{3}{*}{$\begin{array}{l}\text { United Kingdom } \\
\text { (UK) }\end{array}$} & \multirow[t]{3}{*}{20,620} \\
\hline France (FR) & 7,201 & Norway (NO) & 1,313 & & \\
\hline Germany (DE) & 6,973 & Portugal (PT) & 712 & & \\
\hline
\end{tabular}

Panel B: Summary statistics

\begin{tabular}{lrrrrrr} 
Variables & $\mathrm{N}$ & Mean & $\begin{array}{r}\text { Standard } \\
\text { deviation }\end{array}$ & $\mathrm{Q} 1$ & $\mathrm{Q} 2$ & $\mathrm{Q} 3$ \\
\hline$R E T$ & 56,696 & 0.1150 & 0.4671 & -0.1670 & 0.0499 & 0.3075 \\
$N I$ & 56,696 & 0.0238 & 0.0972 & 0.0003 & 0.0055 & 0.0660 \\
OCI & 56,696 & 0.0075 & 0.0714 & -0.0031 & 0 & 0.0038 \\
$C I$ & 56,696 & 0.0313 & 0.1182 & 0 & 0.0032 & 0.0694 \\
UNREAL & 56,696 & 0.0002 & 0.0258 & 0 & 0 & 0 \\
FOREX & 56,696 & -0.0003 & 0.0263 & 0 & 0 & 0 \\
REVAL & 56,696 & 0.0005 & 0.0369 & 0 & 0 & 0 \\
SIZE & 56,696 & 13.5226 & 2.6457 & 11.555 & 13.3995 & 15.3396 \\
$L E V$ & 56,696 & 0.5615 & 0.2478 & 0.4034 & 0.5886 & 0.7439 \\
\hline
\end{tabular}

Panel C: Spearman correlation

\begin{tabular}{lccccccc} 
& $R E T$ & $N I$ & OCI & $C I$ & UNREAL & FOREX & REVAL \\
\hline RET & 1 & & & & & & \\
$N I$ & $0.312^{* * *}$ & 1 & & & & & \\
OCI & $0.094^{* * *}$ & 0.004 & 1 & & & & \\
CI & $0.295^{* * *}$ & $0.800^{* * *}$ & $0.415^{* * *}$ & 1 & & & \\
UNREAL & $0.102^{* * *}$ & $-0.014^{* * *}$ & $0.115^{* * *}$ & $0.067^{* * *}$ & 1 & & \\
FOREX & $0.027^{* * *}$ & -0.003 & $0.160^{* * *}$ & $0.042^{* * *}$ & 0.002 & 1 & \\
REVAL & $0.020^{* * *}$ & $0.046^{* * *}$ & $0.123^{* * *}$ & $0.100^{* * *}$ & -0.001 & 0 & 1 \\
\hline
\end{tabular}

Table 1 reports descriptive statistics for the sample of sixteen European countries reported in Panel A. Years covered are 1991 to 2005 . Reported statistics are for the sub-sample used in the value relevance analysis. RET are cumdividend stock returns measured over a year period ending 3 months after the balance sheet date, $N I$ is net income available to common, $O C I$ is other comprehensive income measured as $\triangle B V$-(NI-DIV-NETCAP), where $\triangle B V$ is change in equity, $D I V$ are dividends paid, and NETCAP are net capital contributions. $C I$ is comprehensive income measured as $O C I+N I$. REVAL is change in revaluation reserve, FOREX is change in foreign currency translation adjustments reported in equity, and UNREAL is unrealized security gains and losses reported directly in equity. All accounting variables are measured on per share basis and scaled by the lagged price per share, SIZE is the natural logarithm of market capitalization at fiscal year end, and $L E V$ is accounting leverage measured as total liabilities divided by total assets. $* * *$ indicates statistical significance at the one percent level or higher. 
The sample of sixteen countries over a significant time period effectively picks up the effect of many national regulations for reporting dirty surplus components. The majority of national GAAPs did not require disclosure of other comprehensive income figure during the research period which precludes us from carrying out a full analysis using as-reported numbers as suggested by Chambers et al. (2007). ${ }^{10}$ We use the following proxy for other comprehensive income:

$$
O C I=\triangle B V-N I+D I V+N E T C A P,
$$

where $O C I$ is other comprehensive income, $\triangle B V$ is change in book value of equity (item WC03501), NI is net income available to common (WC01751), DIV is dividends paid (WC04551), and NETCAP is net capital contributions (WC04751-WC04251). We also inquire usefulness of three components of dirty surplus reported in equity reserves: asset revaluations (REVAL), unrealized foreign exchange gains and losses (FOREX), and unrealized gains and losses on securities (UNREAL). REVAL is estimated as the change in revaluation reserve (change in item WC03492), FOREX is the change in foreign currency translation adjustments reported in equity (change in WC03497) and UNREAL is the change in unrealized security gains and losses reported directly in equity (change in WC03498).

Table 2 presents summary statistics for the importance of other comprehensive income across different countries. To access the relative weight of other comprehensive income we divide the absolute value of other comprehensive income by the sum of the absolute value of other comprehensive income and the absolute value of net income: $\operatorname{abs}(O C I) /(\operatorname{abs}(O C I)+\operatorname{abs}(N I))$. Panel A documents high reliance on other comprehensive income in the pooled sample (the median weight of $O C I$ is 24.1 percent) and substantial variation across countries (the range is 18.9 percentage point). Panel B further analyses whether other comprehensive income has gained in importance during our sample period. We regress relative weights of $O C I$ on a trend variable and show that dirty surplus has increased over time; this increase was though small in economic terms.

\footnotetext{
${ }^{10}$ As our pooled tests provide evidence consistent with the "as-reported tests" in Chambers et al. (2007), we suggest that error-in-variables problems do not pose a significant threat to our analysis.
} 
Table no. 2

Relative Importance of Incremental Comprehensive Income

Panel A: Descriptive statistics

\begin{tabular}{|c|c|c|c|c|c|c|c|c|c|c|c|c|c|c|c|c|c|}
\hline & \multirow[t]{2}{*}{ Pooled } & \multicolumn{16}{|c|}{ Country-level } \\
\hline & & $\mathrm{AU}$ & $\mathrm{BE}$ & $\mathrm{DK}$ & FI & FR & $\mathrm{DE}$ & GR & IR & IT & $\mathrm{NL}$ & $\mathrm{NO}$ & $\mathrm{PT}$ & $\mathrm{ES}$ & SW & $\mathrm{CH}$ & UK \\
\hline Mean & 0.329 & 0.314 & 0.259 & 0.246 & 0.271 & 0.247 & 0.309 & 0.441 & 0.325 & 0.298 & 0.340 & 0.300 & 0.383 & 0.365 & 0.287 & 0.316 & 0.381 \\
\hline Median & 0.241 & 0.230 & 0.164 & 0.162 & 0.188 & 0.151 & 0.241 & 0.401 & 0.236 & 0.205 & 0.278 & 0.194 & 0.334 & 0.340 & 0.182 & 0.246 & 0.296 \\
\hline
\end{tabular}

Panel B: Trend analysis

\begin{tabular}{ll} 
& TREND \\
\hline Relative importance of $O C I$ & $\begin{array}{l}0.001 \\
(3.57)^{* * *}\end{array}$
\end{tabular}

Table 2 reports statistics for the sample of sixteen countries: Austria, Belgium, Denmark, Finland, France, Germany, Greece, Ireland, Italy, Netherlands, Norway, Portugal, Spain, Sweden, Switzerland and United Kingdom. Panel A reports descriptive statistics for the relative importance of other comprehensive income $(O C I)$. Relative importance of $O C I$ is defined as abs $(O C I) /(\operatorname{abs}(O C I)+\operatorname{abs}(N I))$, where $N I$ is net income available to common, $O C I$ is other comprehensive income measured as $\triangle B V$ - $(N I-D I V$ NETCAP). Panel B reports the slope coefficient of the OLS regression of the relative importance of other comprehensive income on the trend variable. The t-statistic is based on the Huber-White standard error and is reported in parentheses, and *** indicate statistical significance at the one percent level or higher. 
In the next section we compare the alternative performance of four different income measures: (i) net income (NI), (ii) $N I$ plus incremental comprehensive income (OCI), (iii) aggregated comprehensive income $(C I=O C I+N I)$, and (iv) $N I$ plus three individual components of $O C I$ - REVAL, UNREAL, and FOREX - to observe if these components have differential value relevance qualities (Dhaliwal et al. 1999; O'Hanlon and Pope 1999). We also use an alternative measure of other comprehensive income by summing REVAL, UNREAL, and FOREX, but these results are not reported in the tables. ${ }^{11}$

\section{Model construction}

A number of models are constructed in undertaking our research agenda. We start with the information perspective (as the primary model that has been tested) by using a price change model. A non-linear arctan model is then constructed to examine if the results are robust to temporary components imbedded in comprehensive income. A measurement perspective may be particularly relevant for the less efficient European markets and for this we use a price levels association model. A further test of usefulness is the ability to predict future cash flows and to influence analyst price revisions. Finally, we run reverse piecewise regressions conditioned on negative and positive stock returns in order to examine conditional conservatism.

Tests are performed on two levels of data. A pooled sample is used to answer the macro question whether comprehensive income is generally a more useful measure of firm performance. If the properties of financial accounting vary with culture and reporting incentives (Ball et al. 2000; Burgstahler et al. 2006), then the timing, the amount, and the properties of comprehensive income components will be a part function of prevailing national GAAPs and their application (Isidro et al. 2004). Hence, we run micro analyses by decomposing into three sub-samples based on the accounting framework (local GAAP, IFRS and US GAAP) and into individual countries. Four control proxies are applied - firm size, accounting leverage, the relative magnitude of total accruals, and the sign of net income (e.g., Ball and Shivakumar 2005; Barth et al. 1998; Hayn 1995; Daske et al. 2008). Huber-White robust standard errors are used throughout to adjust for potential heteroskedasticity and serial correlation and Vuong tests are used to delineate the statistical significance of the difference in explanatory power across aggregate income specifications (see Vuong 1989; Dechow 1994).

\subsection{Value relevance models}

We examine value relevance from two perspectives - measurement and information.

\section{Information perspective}

Under the information perspective an accounting signal is only informative if it adjusts price given the availability of all other value relevant information. The dependent variable is raw returns or abnormal returns derived from a market model and the independent variable earnings and/or earnings surprises. Surprise being modelled from a random walk as a change in earnings, or an autoregressive or mean reversion model with surprise being the deviation from expectations. Consistent with Dhaliwal et al. (1999), Easton et al. (1992), and O'Hanlon and Pope (1999) we construct models that evaluate different forms of comprehensive income as follows:

$$
\begin{aligned}
& R E T_{j t}=\alpha_{01}+\alpha_{1} N I_{j t}+\varepsilon_{1 j t}, \\
& R E T_{j t}=\alpha_{02}+\alpha_{2} N I_{j t}+\alpha_{3} O C I_{j t}+\varepsilon_{2 j t},
\end{aligned}
$$

\footnotetext{
${ }^{11}$ Results are consistent with those reported and are available from the authors on request.
} 


$$
\begin{aligned}
& R E T_{j t}=\alpha_{03}+\alpha_{4} C I_{j t}+\varepsilon_{3 j t}, \\
& R E T_{j t}=\alpha_{04}+\alpha_{5} N I_{j t}+\alpha_{6} R E V A L_{j t}+\alpha_{7} \text { FOREX }_{j t}+\alpha_{8} U_{N R E A L_{j t}}+\varepsilon_{4 j t},
\end{aligned}
$$

where $R E T_{j t}$ is cum-dividend raw stock returns measured over a year period ending three months after the balance sheet date. Because prior research has also shown that changes in income adds incremental information over and above the earnings level variable (Easton and Harris 1991) we add the following earnings change model where $\Delta$ is the change operator (e.g., Francis and Schipper 1999):

$$
\begin{aligned}
& R E T_{j t}=\xi_{01}+\xi_{1} N I_{j t}+\xi_{2} \Delta N I_{j t}+v_{1 j t} \\
& R E T_{j t}=\xi_{02}+\xi_{3} N I_{j t}+\xi_{4} \Delta N I_{j t}+\xi_{5} O C I_{j t}+\xi_{6} \Delta O C I_{j t}+v_{2 j t}, \\
& R E T_{j t}=\xi_{03}+\xi_{7} C I_{j t}+\xi_{8} \Delta C I_{j t}+v_{3 j t}, \\
& R E T_{j t}=\xi_{04}+\xi_{9} N I_{j t}+\xi_{10} \Delta N I_{j t}+\xi_{11} R E V A L_{j t}+\xi_{12} F O R E X_{j t}+\xi_{13} U N R E A L_{j t}+v_{4 j t}
\end{aligned}
$$

The (a) models serve as the base net income model derived from basic operating income concepts with the subsequent models use comprehensive income components $O C I_{j t}$ in addition to net income (model (b)), replace $N I_{j t}$ with total comprehensive income $C I_{j t}$ (model (c)) and the (d) model evaluate separate components. All income and components are measured on a per share basis and scaled by lagged price per share with $j$ signifying a firm and $t$ is a year sub-script.

\section{Measurement perspective}

The measurement perspective is tested by using a levels based model, widely applied in the academic literature (e.g., Collins et al. 1997; Francis and Schipper 1999; Lev and Zarowin 1999), but with limited application in comprehensive income based research. If Continental Code law countries represent incomplete valuation markets, financial accounting outputs represent a potential valuation aid. That is, accounting data may well provide a measurement basis for stock prices. We rely on Ohlson (1995) to derive a price specification of the measurement regression as follows:

$$
\begin{aligned}
& P_{j t}=\delta_{01}+\delta_{1} N I_{j t}+\delta_{2} B V_{j t-1}+w_{1 j t}, \\
& P_{j t}=\delta_{02}+\delta_{3} N I_{j t}+\delta_{4} O C I_{j t}+\delta_{5} B V_{j t-1}+w_{2 j t}, \\
& P_{j t}=\delta_{03}+\delta_{6} C I_{j t}+\delta_{7} B V_{j t-1}+w_{3 j t}, \\
& P_{j t}=\delta_{04}+\delta_{8} N I_{j t}+\delta_{9} B V_{j t-1}+\delta_{10} R E V A L_{j t}+\delta_{11} \text { FOREX }_{j t}+\delta_{12} U N R E A L_{j t}+w_{4 j t}
\end{aligned}
$$

where $P_{j t}$ is price per share three months after the balance sheet date and $B V_{j t-1}$ is book value of equity. As price regressions are known to suffer from scale problems, we use the Weighted Least Squares (WLS) estimator with analytical weights equal to the inverse of the square of price (see Easton and Sommers 2003).

\section{Predicting cash flows}

One stated purpose of measurement by FASB and the IASB is its ability to predict future performance, operationalised by future cash flows. As this test does not rely on market prices it also provides a robustness test for the value relevance models. If comprehensive income is more value relevant than net income, then it should have a higher association with future cash flows. We apply the following cross-sectional regressions to examine the relative predictive ability of different income measures:

$$
\begin{aligned}
& C F O_{j t}=\alpha_{01}+\alpha_{1} N I_{j t-1}+\varepsilon_{1 j t}, \\
& C F O_{j t}=\alpha_{02}+\alpha_{2} C I_{j t-1}+\varepsilon_{2 j t}, \\
& C F O_{j t}=\alpha_{03}+\alpha_{3}\left(N I+O C I_{-} \text {COMPONENT } T_{k}\right)_{j t-1}+\varepsilon_{3 j t},
\end{aligned}
$$

where $C F O_{j t}$ is cash flow from operations as reported in the cash flow statement and OCI_COMPONENT $T_{k}$ is one of three components of other comprehensive income (i.e. REVAL, 
UNREAL, and FOREX) with all variables scaled by average total assets. If comprehensive income is a better predictor of future cash flows we would expect to see significantly higher regression $\mathrm{R}^{2}$ in models $(4 \mathrm{~b})$ and $(4 \mathrm{c})$. We have also considered incorporating changes in income measures into analysis with very similar results.

\section{Revision of financial analyst forecasts}

Financial analysts are important users and distributors of financial information and another test is to examine if they incorporate other comprehensive income in equity valuation through revisions in price forecasts. Research to date on this issue has been limited to one study by Hirst and Hopkins (1998). ${ }^{12}$ We extend this research by asking which income measure can better explain the change in the consensus analysts' forecast of firm's price per share during the coming year by the following regressions:

$$
\begin{aligned}
& \operatorname{PREVIS}_{j t}=\alpha_{01}+\alpha_{1} N I_{j t}+\alpha_{2} \Delta N I_{j t}+\alpha_{3} R E T_{j t-1}+\alpha_{4} B T M_{j t}+\varepsilon_{1 j t}, \\
& \text { PREVIS }_{j t}=\alpha_{02}+\alpha_{5} N I_{j t}+\alpha_{6} \Delta N I_{j t}+\alpha_{7} O C I_{j t}+\alpha_{8} \Delta O C I_{j t} \text {, } \\
& +\alpha_{9} R E T_{j t-1}+\alpha_{10} B T M_{j t}+\varepsilon_{2 j t} \text {, } \\
& \text { PREVIS }_{j t}=\alpha_{03}+\alpha_{11} C I_{j t}+\alpha_{12} \Delta C I_{j t}+\alpha_{13} R E T_{j t-1}+\alpha_{14} B T M_{j t}+\varepsilon_{3 j t} \text {, } \\
& \text { PREVIS }_{j t}=\alpha_{04}+\alpha_{15} N I_{j t}+\alpha_{16} \Delta C I_{j t}+\alpha_{17} R E V A L_{j t}+\alpha_{18} \text { FOREX }_{j t}+\alpha_{19} \text { UNREAL }_{j t} \\
& +\alpha_{20} R E T_{j t-1}+\alpha_{21} B T M_{j t}+\varepsilon_{4 j t} \text {, }
\end{aligned}
$$

where $P R E V I S_{j t}$ is a revision (change) in the analysts' mean target estimate of price per share during an annual period ending three months after the balance sheet date scaled by the lagged price per share. A three-months-window is used to ensure that accounting information is available to analysts and all income variables are as previously defined. In addition to earnings, we use earnings surprises to proxy for unexpected information in current earnings. We add two control variables as surrogates for other information that analysts use. Momentum in stock prices is controlled by including the observed return over the past year $\left(R E T_{j t-1}\right)$ and the impact of intangibles and growth factors is proxied by the book-to-market ratio at the end of the fiscal year $\left(B T M_{j t}\right)$. The marginal usefulness of other comprehensive income is observed by testing the statistical significance of coefficient $\alpha_{5}$ and predictive ability by $\mathrm{R}^{2} \mathrm{~s}$.

\subsection{Temporary components and lag effects}

Previous research showed that accounting earnings tend to lag the stock market in recognition of economic events and when there are varying degrees of temporary components (Warfield and Wild 1992). To control for the temporary component issue we assume a non-linear S-shaped relationship - convex for good news and concave for bad news - for large earnings the price response is expected to decrease because of a relatively higher transitory component in earnings (surprises) as follows:

$$
\begin{aligned}
& R E T_{j t}=\beta_{01}+\beta_{1} \arctan \left(\beta_{2} N I_{j t}\right)+u_{1 j t}, \\
& R E T_{j t}=\beta_{02}+\beta_{3} \arctan \left(\beta_{4} N I_{j t}+\beta_{5} O C I_{j t}\right)+u_{2 j t}, \\
& R E T_{j t}=\beta_{03}+\beta_{6} \arctan \left(\beta_{7} C I_{j t}\right)+u_{3 j t},
\end{aligned}
$$

where all variables are as for model (1). ${ }^{13}$ We also aggregate over longer time periods consistent with Easton et al. (1992) as an additional test.

\footnotetext{
${ }^{12}$ In an experimental setting, Hirst and Hopkins (1998) concludes that the clear display of dirty surplus items enhances analysts' ability to detect earnings management.

${ }^{13}$ We have also considered a model with the components of other comprehensive income. However, convergence for this estimation was not achieved.
} 


\subsection{Timeliness and accounting conservatism}

The concept of timely loss recognition and conditional conservatism recognises usefulness of accounting for contracting. According to Guay and Verrecchia (2006), the incremental timeliness of bad news over good news (conditional conservatism) increases the efficiency of debt contracting by providing timely information on bad news in valuing the claims of debt-holders. Conditional conservatism also enhances the efficiency of debt contracting by transferring control to the debtholders more quickly as a result of debt covenant violations (Ball and Shivakumar 2005). Moreover, timely loss recognition and conditional conservatism limits dividend payouts, tax payments and management compensation and thus increases the efficiency of these contracts. We examine the impact of aggregated comprehensive income on timing issues, specifically whether it switches the emphasis from a more timely incorporation of loss components to gain components to assess decision usefulness in contracting. ${ }^{14}$

Following Basu (1997) and Ball et al. (2000) cross-sectional piecewise linear regressions of earnings on stock returns are estimated as follows:

$$
\begin{aligned}
& N I_{j t}=\gamma_{01}+\gamma_{1} R D_{j t}+\gamma_{2} R_{j t}+\gamma_{3} R D_{j t} \times R_{j t}+\varepsilon_{1 j t}, \\
& O C I_{j t}=\gamma_{02}+\gamma_{4} R D_{j t}+\gamma_{5} R_{j t}+\gamma_{6} R D_{j t} \times R_{j t}+\varepsilon_{2 j t},
\end{aligned}
$$

where $R_{j t}$ is the change in the market value of equity inclusive of dividends over the fiscal year, adjusted for the country-year mean return. $R D_{j t}$ is a dummy variable which takes the value of one if stock returns are negative and zero otherwise. In this setup, the coefficients $\gamma_{2}$ and $\gamma_{3}$ signal the timeliness of good news and the incremental timeliness of loss recognition (conditional conservatism) in net income, respectively. The timeliness of bad news is captured by $\gamma_{2}+\gamma_{3}$. Positive and statistically significant coefficients $\gamma_{5}+\gamma_{6}$ and $\gamma_{6}$ will indicate the relevance of other comprehensive income in debt contracting. As comprehensive income $(C I)$ is the sum of net income $(N I)$ and other comprehensive income $(O C I)$, conditional conservatism and the timeliness of loss recognition in comprehensive income can be calculated as $\gamma_{3}+\gamma_{6}$ and $\gamma_{2}+\gamma_{3}+\gamma_{5}+\gamma_{6}$, respectively. Roychowdhury and Watts (2007) show that the performance of the model improves significantly when model variables are aggregated over a time span of three years and we also perform this analysis.

\section{Pooled results \\ 5.1 Information perspective}

Table 3 reports results from an information perspective or the impact on the change in prices. We replicate models examined in prior research by applying income levels as explanatory factors (Panel A), changes in income (Panel B), and control for temporary components by using a non-linear model (Panel C). There are three consistent results. First, both measures of income and income changes are positively related to price changes. Second, incremental comprehensive income components are always significant and positive when added separately to net income. This is driven by unrealized increments on marketable securities held-for-resale. Third, when comprehensive income is reported in the aggregate form then the coefficient is lower and the predictive power of the equation is reduced (Z-statistic -4.38). Results are robust to the non-linear (arctan) model and adding in the change in income to test for earnings surprises (Z-test -3.74, 5.70). We also increase the window of our analysis by aggregating returns and income variables over an interval of five and ten years consistent with Easton et al. (1992). Although the overall

\footnotetext{
${ }^{14}$ Some contractual settings may also benefit from the timely recognition of economic gains. Timeliness of good news will mitigate the myopic behavior resulting from the manager's limited tenure (Watts 2003). Debt repricing creates also demand for timely gains recognition (Ball et al. 2008). Therefore, we report results for the timeliness of good news recognition as well.
} 
power of our tests substantially increases (results are not tabulated), the predictive ability of comprehensive income is still lower than of net income. 
Table no. 3

Value Relevance - Information

\begin{tabular}{|c|c|c|c|c|c|c|c|c|c|}
\hline \multicolumn{10}{|c|}{ Panel A: Price Returns } \\
\hline & Intercept & $N I$ & $O C I$ & $C I$ & UNREAL & $R E V A L$ & FOREX & $\mathrm{R}^{2}$ & Z-test \\
\hline Model 1a & $\begin{array}{l}0.090 \\
(43.54)^{* * *}\end{array}$ & $\begin{array}{l}1.032 \\
(38.58)^{* * *}\end{array}$ & & & & & & 0.046 & \\
\hline Model 1b & $\begin{array}{l}0.088 \\
(42.22)^{* * *}\end{array}$ & $\begin{array}{l}1.042 \\
(38.97)^{* * *}\end{array}$ & $\begin{array}{l}0.323 \\
(10.11)^{* * *}\end{array}$ & & & & & 0.049 & \\
\hline Model 1c & $\begin{array}{l}0.090 \\
(44.14)^{* * *}\end{array}$ & & & $\begin{array}{l}0.794 \\
(37.82)^{* * *}\end{array}$ & & & & 0.040 & $-4.38^{* * *}$ \\
\hline Model 1d & $\begin{array}{l}0.090 \\
(43.56)^{* * *}\end{array}$ & $\begin{array}{l}1.032 \\
(38.54)^{* * *}\end{array}$ & & & $\begin{array}{l}0.163 \\
(2.29)^{* *}\end{array}$ & $\begin{array}{l}-0.024 \\
(0.41)\end{array}$ & $\begin{array}{l}0.075 \\
(0.78)\end{array}$ & 0.046 & \\
\hline
\end{tabular}

Panel B: Returns specification - adding changes in income

\begin{tabular}{|c|c|c|c|c|c|c|c|c|c|c|c|c|}
\hline & Intercept & $N I$ & $\Delta N I$ & $O C I$ & $\triangle O C I$ & $C I$ & $\Delta C I$ & UNREAL & REVAL & FOREX & $\mathrm{R}^{2}$ & Z-test \\
\hline Model 2a & $\begin{array}{l}0.104 \\
(46.19)^{* * *}\end{array}$ & $\begin{array}{l}0.977 \\
(31.11)^{* * *}\end{array}$ & $\begin{array}{l}0.125 \\
(2.90)^{* * *}\end{array}$ & & & & & & & & 0.050 & \\
\hline Model 2b & $\begin{array}{l}0.101 \\
(45.27)^{* * *}\end{array}$ & $\begin{array}{l}0.985 \\
(31.34)^{* * *}\end{array}$ & $\begin{array}{l}0.123 \\
(2.85)^{* * *}\end{array}$ & $\begin{array}{l}0.289 \\
(8.16)^{* * *}\end{array}$ & $\begin{array}{l}0.017 \\
(2.32)^{* *}\end{array}$ & & & & & & 0.052 & \\
\hline Model 2c & $\begin{array}{l}0.105 \\
(47.88)^{* * *}\end{array}$ & & & & & $\begin{array}{l}0.752 \\
(29.66)^{* * *}\end{array}$ & $\begin{array}{l}0.051 \\
(2.45)^{* *}\end{array}$ & & & & 0.041 & $-3.74^{* * *}$ \\
\hline Model 2d & $\begin{array}{l}0.104 \\
(46.21)^{* * * *}\end{array}$ & $\begin{array}{l}0.976 \\
(31.07)^{* * *}\end{array}$ & $\begin{array}{l}0.125 \\
(2.90)^{* * *}\end{array}$ & & & & & $\begin{array}{l}0.182 \\
(2.39)^{* *}\end{array}$ & $\begin{array}{l}-0.009 \\
(0.15)\end{array}$ & $\begin{array}{l}0.061 \\
(0.68)\end{array}$ & 0.050 & \\
\hline
\end{tabular}

Panel C: Returns specification - non-linear (arctan)

Model 6a

\begin{tabular}{|c|c|c|c|c|}
\hline Intercept & $\beta_{1}$ & $N I$ & OCI $\quad C I$ & $\mathrm{R}^{2}$ \\
\hline $\begin{array}{l}0.069 \\
(29.17)^{* * *}\end{array}$ & $\begin{array}{l}0.257 \\
(17.38)^{* * *}\end{array}$ & $\begin{array}{l}7.682 \\
(11.15)^{* * *}\end{array}$ & & 0.058 \\
\hline 0.068 & 0.262 & 7.471 & 1.632 & 0.059 \\
\hline
\end{tabular}

Model 6b 


\begin{tabular}{llllll} 
& $(28.80)^{* * *}$ & $(17.22)^{* * *}$ & $(11.30)^{* * *}(6.77)^{* * *}$ & & \\
Model 6c & 0.074 & 0.199 & 9.204 & 0.050 & $-5.70^{* * *}$ \\
& $(33.37)^{* * *}$ & $(20.72)^{* * *}$ & $(11.62)^{* * *}$ & \\
\hline
\end{tabular}

Table 3 reports results of the value relevance analysis for a pooled sample of sixteen countries: Austria, Belgium, Denmark, Finland, France, Germany, Greece, Ireland, Italy, Netherlands, Norway, Portugal, Spain, Sweden, Switzerland and United Kingdom. Years covered are 1991 to 2005 . Dependent variable in all models is cum-dividend stock returns $\left(R E T_{j t}\right)$ measured over a year period ending three months after the balance sheet date. Independent variables: $N I$ is net income available to common, $O C I$ is other comprehensive income measured as $\triangle B V$ - $(N I-D I V-N E T C A P)$, where $\triangle B V$ is change in equity, $D I V$ are dividends paid, and $N E T C A P$ are net capital contributions. $C I$ is comprehensive income measured as $O C I+N I$. REVAL is change in revaluation reserve, FOREX is change in foreign currency translation adjustments reported in equity, and UNREAL is unrealized security gains and losses reported directly in equity. All accounting variables are measured on per share basis and scaled by the lagged price per share. Panel A and B report results of the OLS regression, while Panel C estimates a non-linear model of the form $R E T_{j t}=\beta_{0}+\beta_{1} \arctan \left(\beta_{2} X_{j t}\right)+u_{j t}$, where $\arctan$ is an inverse of tangent. ${ }^{*},{ }^{* *}$ and ${ }^{* * *}$ indicate statistical significance at 10,5 and 1 percent, respectively. T-statistics are based on the Huber-White standard errors and are reported in parentheses. The Z-test returns the value of the Vuong statistic comparing the explanatory power of a model with the explanatory power of the base model (i.e. model 1a, 2a, or $6 a)$. 
The results in this section allow some preliminary observations. Studies using similar methods in the UK (O'Hanlon and Pope 1999) and Dutch data (Wang et al. 2006) showed that other comprehensive income has no marginal value relevance. Our results suggest that total incremental comprehensive income (dirty surplus) flows provide incremental value relevant information in the cross-section of sixteen European countries; consistent with the recent findings for the US market (Biddle and Choi 2006; Chambers et al. 2007). However, when decomposed most of the elements of other comprehensive income have no incremental value relevance except for unrealised gains and losses on marketable securities. We also show that when income is reported as an aggregated comprehensive income, that obeys the clean surplus relation, the explanatory power of the value relevance regressions decline. It appears that aggregated comprehensive income is not as informative as net income for European investors.

\subsection{Measurement perspective}

Table 4 reports the results for the price level on accounting income and book value regressions. In all specifications the coefficients on net income and book value are positive and statistically significant $(\mathrm{p}<0.01)$. Whilst, the coefficient on total comprehensive income in model is positive and highly significant, it is also lower than net income with a concurrent and significant drop in predictive power (Z-test -5.71). Other comprehensive income and its disaggregated components have no incremental value relevance, except for FOREX which is only marginally significant. Generally, these results mirror those reported above and indicate, as a measurement tool, net income has higher descriptive and predictive power than comprehensive income or its incremental components. 
Table no. 4

Value Relevance - Measurement

\begin{tabular}{|c|c|c|c|c|c|c|c|c|c|c|}
\hline & Intercept & $N I$ & $O C I$ & $C I$ & $B V$ & UNREAL & REVAL & FOREX & $\mathrm{R}^{2}$ & Z-test \\
\hline Model 3a & $\begin{array}{l}0.780 \\
(22.18)^{* * *}\end{array}$ & $\begin{array}{l}0.568 \\
(12.52)^{* * *}\end{array}$ & & & $\begin{array}{l}0.364 \\
(13.80)^{* * *}\end{array}$ & & & & 0.155 & \\
\hline Model 3b & $\begin{array}{l}0.770 \\
(21.96)^{* * *}\end{array}$ & $\begin{array}{l}0.576 \\
(12.52)^{* * *}\end{array}$ & $\begin{array}{l}0.117 \\
(1.19)\end{array}$ & & $\begin{array}{l}0.366 \\
(13.97)^{* * *}\end{array}$ & & & & 0.156 & \\
\hline Model 3c & $\begin{array}{l}0.736 \\
(21.04)^{* * *}\end{array}$ & & & $\begin{array}{l}0.325 \\
(2.33)^{* *}\end{array}$ & $\begin{array}{l}0.351 \\
(12.98)^{* * *}\end{array}$ & & & & 0.145 & $-5.71^{* * *}$ \\
\hline Model 3d & $\begin{array}{l}0.769 \\
(23.19)^{* * *}\end{array}$ & $\begin{array}{l}0.561 \\
(12.87)^{* * * *}\end{array}$ & & & $\begin{array}{l}0.370 \\
(14.46)^{* * *}\end{array}$ & $\begin{array}{l}0.499 \\
(1.54)\end{array}$ & $\begin{array}{l}0.499 \\
(1.54)\end{array}$ & $\begin{array}{l}0.326 \\
(1.78)^{*}\end{array}$ & 0.156 & \\
\hline
\end{tabular}

Table 2 reports results of the value relevance analysis for a pooled sample of sixteen countries: Austria, Belgium, Denmark, Finland, France, Germany, Greece, Ireland, Italy, Netherlands, Norway, Portugal, Spain, Sweden, Switzerland and United Kingdom. Years covered are 1991 to 2005 . Dependent variable in all models is price per share $\left(P_{j t}\right)$ three months after the balance sheet date. Independent variables: $B V$ is lagged book value of equity, $N I$ is net income available to common, $O C I$ is other comprehensive income measured as $\triangle B V$ - $(N I-D I V$-NETCAP), where $\triangle B V$ is change in equity, $D I V$ are dividends paid, and NETCAP are net capital contributions. $C I$ is comprehensive income measured as $O C I+N I$. REVAL is change in revaluation reserve, FOREX is change in foreign currency translation adjustments reported in equity, and $U N R E A L$ is unrealized security gains and losses reported directly in equity. All accounting variables are measured on per share basis. Models are estimated using the Weighted Least Squares [WLS] estimator with analytical weights equal to the inverse of the square of price (see Easton and Sommers 2003 ). ${ }^{*},{ }^{* *}$ and ${ }^{* * *}$ indicate statistical significance at 10,5 and 1 percent, respectively. T-statistics are based on the Huber-White standard errors and are reported in parentheses. The Z-test returns the value of the Vuong statistic comparing the explanatory power of a model with the explanatory power of the base model (i.e. model 3a). 


\subsection{Cash flows and analyst revisions}

If net income level components have descriptive and information content then we ask whether we can utilise them to predict future operating performance as captured by cash flow from operating activities. We use a regression of future CFO on current period's income and report results in Table 5. 
Table no. 5

Predicting Cash Flows

\begin{tabular}{|c|c|c|c|c|c|c|c|c|}
\hline & Intercept & $N I$ & $C I$ & $N I+U N R E A L$ & $N I+R E V A L$ & $N I+F O R E X$ & $\mathrm{R}^{2}$ & Z-test \\
\hline Model 4a & $\begin{array}{l}0.052 \\
(94.27)^{* * *}\end{array}$ & $\begin{array}{l}0.424 \\
(46.77)^{* * *}\end{array}$ & & & & & 0.168 & \\
\hline Model 4b & $\begin{array}{l}0.057 \\
(102.37)^{* * *}\end{array}$ & & $\begin{array}{l}0.195 \\
(30.67)^{* * *}\end{array}$ & & & & 0.061 & $-22.35^{* * *}$ \\
\hline Model 4c_1 & $\begin{array}{l}0.055 \\
(85.85)^{* * *}\end{array}$ & & & $\begin{array}{l}0.301 \\
(21.59)^{* * *}\end{array}$ & & & 0.114 & $-11.14^{* * *}$ \\
\hline Model 4c_2 & $\begin{array}{l}0.053 \\
(95.59)^{* * *}\end{array}$ & & & & $\begin{array}{l}0.416 \\
(46.22)^{* * *}\end{array}$ & & 0.164 & $-5.56^{* * *}$ \\
\hline Model 4c_3 & $\begin{array}{l}0.053 \\
(96.81)^{* * *}\end{array}$ & & & & & $\begin{array}{l}0.377 \\
(43.73)^{* * *}\end{array}$ & 0.158 & $-11.37^{* * *}$ \\
\hline
\end{tabular}

Table 5 reports results of the CFO prediction analysis for a pooled sample of sixteen countries: Austria, Belgium, Denmark, Finland, France, Germany, Greece, Ireland, Italy, Netherlands, Norway, Portugal, Spain, Sweden, Switzerland and United Kingdom. Years covered are 1991 to 2005. Dependent variable in all models is cash flow from operations $(C F O)$. Independent variables: $N I$ is net income available to common, $C I$ is comprehensive income measured as $O C I+N I$. $O C I$ is other comprehensive income measured as $\triangle B V$-(NI-DIV-NETCAP), where $\triangle B V$ is change in equity, $D I V$ are dividends paid, and NETCAP are net capital contributions. REVAL is change in revaluation reserve, FOREX is change in foreign currency translation adjustments reported in equity, and UNREAL is unrealized security gains and losses reported directly in equity. All variables are scaled by average total assets. ${ }^{*},{ }^{* *}$ and ${ }^{* * *}$ indicate statistical significance at 10,5 and 1 percent, respectively. T-statistics are based on the Huber-White standard errors and are reported in parentheses. The Z-test returns the value of the Vuong statistic comparing the explanatory power of a model with the explanatory power of the base model (i.e. model $4 \mathrm{a}$ ) 
When income is recalculated based on the clean surplus relationship the predictive power of the model significantly declines to about six percent. This suggests that aggregated comprehensive income adds noise into the prediction process. Additional tests also reveal that single dirty surplus components (REVAL, FOREX, and UNREAL) when added to net income and used to predict future period CFO have an inferior performance than net income alone. Again the lower predictive ability of comprehensive income supports our notion that net income is a superior measure of firm's performance from the general investor perspective.

To further test value relevance we use the change in the consensus forecast of stock price during the year as a proxy for the revision in analyst forecasts. Results are reported in Table 6 . We observe control variables, past returns (positive) and book-to-market (negative), are significantly different from zero in all model specifications $(\mathrm{p}<0.01)$. The sign on past returns is as expected and shows price momentum, whilst the negative coefficient on book-to-market indicates, for companies with lower intangibles and growth options, price revisions tend to be negative. 
Table no. 6

Analyst Forecasted Price Revisions

\begin{tabular}{|c|c|c|c|c|c|c|c|c|c|c|c|c|c|c|}
\hline & Intercept & $N I$ & $\Delta N I$ & $O C I$ & $\triangle O C I$ & $C I$ & $\Delta C I$ & UNREAL & REVAL & FOREX & $R E T$ & BTM & $\mathrm{R}^{2}$ & Z-test \\
\hline $5 a$ & $\begin{array}{l}0.041 \\
(3.32)^{* * *}\end{array}$ & $\begin{array}{l}0.642 \\
(4.69)^{* * *}\end{array}$ & $\begin{array}{l}0.250 \\
(2.77)^{* * *}\end{array}$ & & & & & & & & $\begin{array}{l}0.812 \\
(25.03)^{* * *}\end{array}$ & $\begin{array}{l}-0.088 \\
(3.73)^{* * *}\end{array}$ & 0.458 & \\
\hline $5 b$ & $\begin{array}{l}0.043 \\
(3.47)^{* * *}\end{array}$ & $\begin{array}{l}0.649 \\
(4.79)^{* * *}\end{array}$ & $\begin{array}{l}0.267 \\
(3.16)^{* * *}\end{array}$ & $\begin{array}{l}0.733 \\
(4.38)^{* * *}\end{array}$ & $\begin{array}{l}-0.291 \\
(1.83)^{*}\end{array}$ & & & & & & $\begin{array}{l}0.809 \\
(25.20)^{* * *}\end{array}$ & $\begin{array}{l}-0.097 \\
(4.18)^{* * *}\end{array}$ & 0.465 & \\
\hline $5 c$ & $\begin{array}{l}0.044 \\
(3.55)^{* * *}\end{array}$ & & & & & $\begin{array}{l}0.631 \\
(5.86)^{* * *}\end{array}$ & $\begin{array}{l}-0.028 \\
(0.32)\end{array}$ & & & & $\begin{array}{l}0.813 \\
(25.66)^{* * *}\end{array}$ & $\begin{array}{l}-0.092 \\
(3.89)^{* * *}\end{array}$ & 0.460 & 0.11 \\
\hline $5 d$ & $\begin{array}{l}0.041 \\
(3.29)^{* * *}\end{array}$ & $\begin{array}{l}0.628 \\
(4.66)^{* * *}\end{array}$ & $\begin{array}{l}0.257 \\
(2.92)^{* * *}\end{array}$ & & & & & $\begin{array}{l}0.084 \\
(0.17)\end{array}$ & $\begin{array}{l}0.072 \\
(2.28)^{* *}\end{array}$ & $\begin{array}{l}0.823 \\
(4.39)^{* * *}\end{array}$ & $\begin{array}{l}0.810 \\
(24.98)^{* * *}\end{array}$ & $\begin{array}{l}-0.088 \\
(3.77)^{* * *}\end{array}$ & 0.460 & \\
\hline
\end{tabular}

Table 6 explains analyst price revisions for a pooled sample of sixteen countries: Austria, Belgium, Denmark, Finland, France, Germany, Greece, Ireland, Italy, Netherlands, Norway, Portugal, Spain, Sweden, Switzerland and United Kingdom. Years covered are 1991 to 2005 . Dependent variable in all models is analyst price revisions $\left(P R E V I S_{j t}\right)$ defined as a revision (change) in the analysts' consensus price per share for a year period ending three months after the balance sheet date scaled by the lagged (market) price per share. Independent variables: $N I$ is net income available to common, $C I$ is comprehensive income measured as $O C I+N I$. $O C I$ is other comprehensive income measured as $\triangle B V$-(NI-DIV-NETCAP), where $\triangle B V$ is change in equity, $D I V$ are dividends paid, and NETCAP are net capital contributions. $R E V A L$ is change in revaluation reserve, $F O R E X$ is change in foreign currency translation adjustments reported in equity, and UNREAL is unrealized security gains and losses reported directly in equity. All accounting variables are measured on per share basis and scaled by the lagged price per share. $R E T_{j t}$ is the lagged one year change in stock price during the year, $B T M_{j t}$ is the book-tomarket ratio at the end of the fiscal year, while $\Delta$ is the change operator. ${ }^{* * *}$ and ${ }^{* * *}$ indicate statistical significance at 10,5 and 1 percent, respectively. T-statistics are based on the Huber-White standard errors and are reported in parentheses. The Z-test returns the value of the Vuong statistic comparing the explanatory power of a model with the explanatory power of the base model (i.e. model 5a). 
Results show that comprehensive income components and total comprehensive income have a positive association with analyst price revisions. A breakdown of components shows that foreign exchange and asset revaluations are driving incremental significance of other comprehensive income. The next question we ask is whether analysts utilize the embedded information in comprehensive income and are able to unravel information. For example, delineating if there is real potential wealth increments through sale, by takeover, exchange gains, or as a signal of increased borrowing capacity. Finding and using this information requires some considerable expertise and may be beyond the average investors capabilities or willingness to invest in such information analysis. However, analysts also do not rely more on comprehensive income indicated by a comparable explanatory power of model (5c) and model (5a). We conclude that comprehensive income potentially favours analysts, but there is only a little gain for analysts from reporting on clean surplus basis.

\subsection{Timeliness and conditional conservatism}

To test the extent of timeliness and conservatism of other comprehensive income we perform the Basu piecewise linear regression with different measures of accounting income as dependent variables. Table 7 reports these results. Evidence from model (7a) in Panel A is consistent with net income incorporating good and bad news in a timely fashion. Consistent with Roychowdhury and Watts (2007) we also find that the performance of the Basu regression improves when net income is accumulated over a time span of three years (see model (7a) in Panel B). Regression's $\mathrm{R}^{2}$ and the coefficient on $R \times R D$ are more than two times higher.

Table no. 7

Timeliness and Conservatism

Dependent variable Independent variables

Panel A: Asymmetric timeliness of income

\begin{tabular}{lllllll} 
& Intercept & $R$ & $R D$ & $R \times R D$ & $\mathrm{R}^{2}$ & $R+R \times R D$ \\
\cline { 2 - 7 } Model 7a: NI & 0.047 & 0.008 & -0.005 & 0.103 & 0.071 & 0.111 \\
& $(56.41)^{* * *}$ & $(3.58)^{* * *}$ & $(4.27)^{* * *}$ & $(28.57)^{* * *}$ & & $(39.05)^{* * *}$ \\
Model 7b: $O C I$ & 0.007 & 0.011 & -0.002 & -0.017 & 0.002 & -0.006 \\
& $(9.34)^{* * *}$ & $(6.54)^{* * *}$ & $(1.83)^{*}$ & $(6.71)^{* * *}$ & & $(3.11)^{* * *}$ \\
\hline
\end{tabular}

Panel B: Cumulating model variables over a time span of 3 years

\begin{tabular}{lllllll} 
Model 7a: NI & 0.170 & 0.022 & -0.097 & 0.217 & 0.146 & 0.239 \\
& $(34.18)^{* * *}$ & $(4.21)^{* * *}$ & $(16.67)^{* * *}$ & $(24.76)^{* * *}$ & & $(33.53)^{* * *}$ \\
Model 7b: $O C I$ & -0.007 & 0.058 & 0.013 & -0.075 & 0.009 & -0.017 \\
& $(0.54)$ & $(5.29)^{* * *}$ & $(1.07)$ & $(6.32)^{* * *}$ & & $(3.73)^{* * *}$ \\
\hline
\end{tabular}

Table 7 reports results of a piecewise linear regression of income on stock returns for a pooled sample of sixteen countries: Austria, Belgium, Denmark, Finland, France, Germany, Greece, Ireland, Italy, Netherlands, Norway, Portugal, Spain, Sweden, Switzerland and United Kingdom. Years covered are 1991 to 2005. Dependent variable is indicated in the first column and is either net income $(N I)$ or other comprehensive income $(O C I)$. $O C I$ is measured as $\triangle B V$-(NI-DIV-NETCAP), where $\triangle B V$ is change in equity, DIV are dividends paid, and NETCAP are net capital contributions. Independent variables: $R$ is the change in the market value of equity inclusive of dividends over the fiscal year and $R D$ is a dummy variable which takes the value of one if stock returns are negative and zero otherwise. Income variables and $R$ are scaled by the market value of equity at the beginning of the fiscal year. $R$ is further adjusted for the country-year mean return. Panel B cumulates return and income variables over three years and then replicates results from Panel A. ${ }^{*},{ }^{* *}$ and ${ }^{* * *}$ indicate statistical significance at 10,5 and 1 percent, respectively. T-statistics are 
based on the Huber-White standard errors and are reported in parentheses. Last column of the table reports the sum of coefficients on $R$ and $R \times R D$ and the associated t-statistic (in parentheses).

We find other comprehensive income incorporates good news in a timely fashion $(0.011$, $\mathrm{p}<0.01)$, but bad news recognition is negative $(-0.006, \mathrm{p}<0.01)$. Thus, other comprehensive income incorporates gains in a more timely fashion than losses and the results hold when the model variables are accumulated over a longer time span. As the (asymmetric) timeliness of comprehensive income is the sum of coefficients from model (7a) and (7b), comprehensive income will be less timely in incorporating bad news and has lower conditional conservatism. This diminishes the contracting relevance and stewardship properties of other comprehensive income. Panel B also shows that comprehensive income is more timely in recognising good news (by 0.058 points) but is less timely in incorporating information on bad news by 0.075 points. This is an economically significant reduction considering that the asymmetric timeliness of net income is at 0.216

We also test the (asymmetric) timeliness of the individual dirty surplus components. Untabulated results are generally week. The only significant result is REVAL as the dependent variable showing that the change in revaluation reserve incorporates bad news in a timely fashion $(0.002, \mathrm{p}<0.05)$ and is incrementally conditionally conservative $(0.003, \mathrm{p}<0.05)$. This result disappears, however, when longer measurement windows are used but unrealised gains and losses on marketable securities become asymmetrically timely in incorporation of economic events $(0.001$, $\mathrm{p}<0.01)$. In summary, reporting comprehensive income in aggregate reduces stewardship efficiency and thus effectiveness in debt contracting.

\section{Results of the micro level analysis 6.1 Country-level analysis}

Because accounting standards and reporting incentives substantially vary across European countries, they affect the composition and presentation of comprehensive income. Therefore, we replicate some tests for (a) high-versus-low investor protection countries, and for (b) each of sixteen countries. To split our sample into high and low investor protection regimes, we rely on the antiself-dealing index from Djankov et al. (2008). Countries with the anti-self-dealing index lower (higher) than the sample median form the "Low" ("High") investor protection sub-sample. Results of the analysis are presented in Table 8. In general, results are quite similar for "Low" and "High" protection sub-samples, although findings for high investor protection countries are less pronounced in statistical terms.

Results of the country-level analysis are also generally consistent with the pooled estimations. In Panel A we report significance levels for t-tests on the incremental value relevance of other comprehensive income (model (1b)) and then compare the explanatory power of comprehensive income (model (1c)) with the explanatory power of net income (model (a)) using a Z-test. Incremental comprehensive income $(O C I)$ is positively associated with returns in fifteen out of sixteen countries and significant in nine. Net income significantly dominates comprehensive income in seven countries. 
Table no. 8

Individual Country Analysis

\section{Investor}

Test Pooled protection

description $\mathrm{M}$ result Low High

Panel A: Value relevance analysis

$\begin{array}{llll}\text { OCI } & 1 \mathrm{~b} & >^{* * *} & >^{* * *} \\ \text { CI vs. NI } & \text { la,c } & <^{* * *} & <^{* *}<^{* * *}\end{array}$

Individual countries compared with pooled results

Same sign (italic if $p<0.1$ ) Different sign (italic if $p<0.1$ )

\section{Panel B: Predictive ability for CFO}

CI vs. NI $\quad$ 4a,b $\quad<^{* * *} \quad<^{* * *} \quad<^{* * *} \quad$ All, insignificant AU, IT, ES

\section{Panel C: Analyst forecast revisions}

\begin{tabular}{|c|c|c|c|c|}
\hline$O C I$ & $5 b$ & $>^{* * *}$ & $>^{* * *}>$ & $\mathrm{FR}, \mathrm{DE}, I T, N L, E S, S W, C H, \mathrm{UK}$ \\
\hline$C I$ vs. $N I$ & $5 \mathrm{a}, \mathrm{c}$ & $>$ & $>$ & IT, NL, ES, CH, UK \\
\hline
\end{tabular}

AU, DK, FI, FR, DE, GR, IR, IT, NL, NO, PT, ES, SW, $\quad$ BE

$\mathrm{CH}, U K$

$A U, B E, D K, F R, \mathrm{GR}, \mathrm{IR}, I T, N L, N O, \mathrm{ES}, \mathrm{SW}$
FI, DE, PT, CH, UK

\section{Panel D: Timeliness and conservatism of OCI}

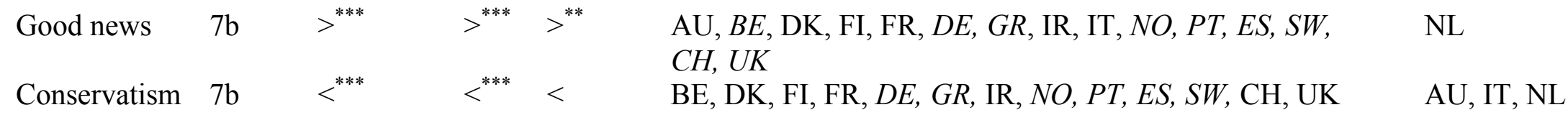

Table 8 replicates previous results for individual countries: Austria, Belgium, Denmark, Finland, France, Germany, Greece, Ireland, Italy, Netherlands, Norway, Portugal, Spain, Sweden, Switzerland and United Kingdom. Years covered are 1991 to 2005. Panel A replicates results of Table 3 (Panel A). The first row of Panel A shows the sign and significance level of coefficient on $O C I$ in model (1b), while second row compares the $\mathrm{R}^{2}$ of model (1c) and (1a). Panel B replicates results of Table 5. The first row of Panel B compares the $\mathrm{R}^{2}$ of model ( $3 \mathrm{~b}$ ) and (3a). Panel C replicates results of Table 6 . The first row of Panel C shows the sign and significance level of coefficient on $O C I$ in model (5b), while second row compares the $\mathrm{R}^{2}$ of model $(5 \mathrm{c})$ and (5a). The tests in the last two columns were performed only for countries with more than 100 firm-year observations. Panel D replicates results of Table 7 (Panel A). The second and second row of Panel $\mathrm{D}$ show the sign and significance level of coefficient on $R$ and $R \times R D$ in model (7b), respectively. ${ }^{*},{ }^{* *}$ and ${ }^{* * *}$ indicate statistical significance at 10,5 and 1 percent, respectively. Model numbers refer to models specified in text. Sign indicates whether the coefficient is more $(>)$ or less $(<)$ than zero, and whether the $\mathrm{R}^{2}$ of the regression model featuring comprehensive income is larger $(>)$ or smaller $(<)$ than the $\mathrm{R}^{2}$ of the model incorporating net income (applies to last rows of Panels A, B, and C). Investor protection classification is based on the anti-self-dealing index from Djankov et al. (2008). Countries with the anti-self-dealing index lower (higher) than the sample median form the "Low" ("High") investor protection sub-sample. 
Comparing our results with previous country-level studies, we find evidence that 'dirty surplus' flows are incrementally value relevant in The Netherlands and in the UK, in contradiction with the reported findings of O'Hanlon and Pope (1999) and Wang et al. (2006). Differences in the sample composition may explain these results. We use a larger sample which implies less survivorship bias and the data is over a more recent period (1991 to 2005). This suggests results may be time specific and that newly accepted accounting rules (IFRS) might have a hand in driving results. Panel B shows that net income is a significantly better predictor of future operating cash flows than comprehensive income in thirteen of the European countries. Panel C presents results on analysts' price revisions. We use countries with at least 100 firm-year observations leaving a sample of eight major European markets. Evidence is again consistent with the pooled results with other comprehensive income significantly contributing to analysts' price revisions in five of the eight countries. For aggregated comprehensive are not significant on the conventional level in any of the countries.

In Panel D we inquire about the contracting usefulness of other comprehensive income by running the Basu regression with $O C I$ as the dependent variable (model (7b)). The coefficient on returns is positive in all regressions except for The Netherlands and statistically significant in nine countries. However, $O C I$ is not timely in incorporating bad news. Only in Belgium is the sum of the coefficients on returns and the interaction term, significantly greater than zero (results for bad news are not tabulated). The 'conservatism' coefficient is significantly less than zero in six countries, showing that good news is incorporated into other comprehensive income in a more timely fashion than bad news. From a debt-holders perspective, other comprehensive income switches timeliness from bad news to good news and net income would be preferred over comprehensive income in contract negotiations.

\subsection{Influence of reporting frameworks}

In this section the sample is divided into three sub-samples according to the underlying accounting framework by differentiating between local GAAP, IFRS and US GAAP. We then replicate results of the main tests with each of the sub-samples and present results in Table 9. Results for the IFRS and local GAAP sub-samples show that incremental other comprehensive income is value relevant, but aggergated comprehensive income is not. Results for US GAAP are not significant consistent with the results for USA presented in Dhaliwal et al. (1999). Net income under all accounting frameworks is a better predictor of cash flows than comprehensive income calculated from all accounting bases (see Panel B). Panel C shows that while other comprehensive income is incrementally useful for financial analysts under all GAAPs, whether analysts rely more on the aggregate comprehensive or net income for price revisions depends on the sub-sample considered. Under local GAAP net income dominates comprehensive income, while we observe a mirror image for the international GAAP sub-samples. Finally Panel D reveals that other comprehensive income is timely in incorporating good news, but this is not sufficiently offset by the bad news timeliness. Therefore, comprehensive income is less conservative than net income for all sub-samples, although results for US GAAP firms are not statistically pronounced. Generally, we find less significant results for the US GAAP sub-sample.

\subsection{Other robustness tests}

Another way to assess accounting differences is to perform an industry analysis. Unrealized securities gains and losses - the only dirty surplus component that turns out to be relevant across a number of tests - are, for instance, more closely related to operating activities of financial companies (Dhaliwal et al. 1999). Therefore, we replicate our tests for the sub-sample of financial 
(SIC 6000-6999) and non-financial firms. Results of the main analyses are, however, similar in both sub-samples. 
Table no. 9

Reporting Incentives and Accounting Framework

\begin{tabular}{|c|c|c|c|c|c|c|c|c|c|c|c|c|c|c|}
\hline \multirow[t]{2}{*}{ Test description } & \multirow[t]{2}{*}{ M } & Size & & \multicolumn{2}{|c|}{ Leverage } & \multicolumn{2}{|c|}{ Accruals/CFO } & \multicolumn{2}{|c|}{ Sign of net income } & \multicolumn{5}{|c|}{ Accounting framework } \\
\hline & & & Q4 & Q1 & Q4 & Q1 & Q4 & - & + & Local GAAP & IAS & & US-C & AAP \\
\hline \multicolumn{15}{|c|}{ Panel A: Value relevance analysis } \\
\hline$O C I$ & $1 \mathrm{~b}$ & $>^{* * *}$ & $>^{* * *}$ & $>^{* * *}$ & $>^{* * *}$ & $>^{* * *}$ & $>^{* * *}$ & $>^{* *}$ & $>^{* * *}$ & 52,592 & 3,376 & $>^{* * *}$ & 728 & $>$ \\
\hline$C I$ vs. $N I$ & $1 \mathrm{a}, \mathrm{c}$ & $<* * *$ & $<$ & $<$ & $<^{* *}$ & $<$ & $<^{* *}$ & $<$ & $<^{* * *}$ & $52,592<<^{* * *}$ & 3,376 & $<$ & 728 & $<$ \\
\hline \multicolumn{15}{|c|}{ Panel B: Predictive ability for $\mathrm{CFO}$} \\
\hline$C I$ vs. $N I$ & $4 a, b$ & $<^{* * *}$ & $<^{* * *}$ & $<^{* * *}$ & $<^{* * *}$ & $<^{* * *}$ & $<^{* * *}$ & $<^{* * *}$ & $<^{* * *}$ & 27,326 & 1,660 & $<^{* * *}$ & 503 & $<^{* *}$ \\
\hline \multicolumn{15}{|c|}{ Panel C: Analyst forecast revisions } \\
\hline$O C I$ & $5 b$ & $>^{* *}$ & $>$ & $>^{* *}$ & $>^{* * *}$ & $>^{* *}$ & $>$ & $>^{* *}$ & $>^{* * *}$ & 1,341 & 911 & $>$ & 116 & $>$ \\
\hline$C I$ vs. $N I$ & $5 a, c$ & $<$ & $>$ & $<$ & $>$ & $>$ & $<$ & $>$ & $>$ & 1,341 & 911 & $<^{* *}$ & 116 & $<$ \\
\hline \multicolumn{15}{|c|}{ 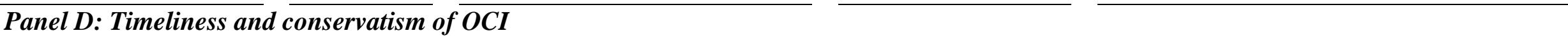 } \\
\hline Good news & $7 \mathrm{~b}$ & $>^{* * *}$ & $>^{* *}$ & $>^{* * *}$ & $>^{* *}$ & $>^{* * *}$ & $>^{* * *}$ & $>^{* *}$ & $>^{* * *}$ & $52,514>^{* * *}$ & 3,416 & $>^{* * *}$ & 772 & $>$ \\
\hline Conservatism & $7 \mathrm{~b}$ & $<^{* * *}$ & $<$ & $<^{* * *}$ & $<^{* * *}$ & $<* * *$ & $<^{* * *}$ & $<$ & $<^{* * *}$ & $52,514<<^{* * *}$ & 3,416 & $<$ & 772 & $<$ \\
\hline
\end{tabular}

Table 9 replicates previous results for different sub-samples formed according to prevailing reporting incentives (only non-financial firms are considered) or accounting framework (complete sample). We use a sample of European countries: Austria, Belgium, Denmark, Finland, France, Germany, Greece, Ireland, Italy, Netherlands, Norway, Portugal, Spain, Sweden, Switzerland and United Kingdom. Years covered are 1991 to 2005. Panel A replicates results of Table 3 (Panel A). The first row of Panel A shows the sign and significance level of coefficient on $O C I$ in model (1b), while second row compares the $\mathrm{R}^{2}$ of model (1c) and (1a). Panel B replicates results of Table 5 . The first row of Panel B compares the $\mathrm{R}^{2}$ of model (3b) and (3a). Panel $\mathrm{C}$ replicates results of Table 6 . The first row of Panel $\mathrm{C}$ shows the sign and significance level of coefficient on $O C I$ in model (5b), while second row compares the $\mathrm{R}^{2}$ of model $(5 \mathrm{c})$ and $(5 \mathrm{a})$. The tests in the last two columns were performed only for countries with more than 100 firmyear observations. Panel D replicates results of Table 7 (Panel A). The second and second row of Panel $\mathrm{D}$ show the sign and significance level of coefficient on $R$ and $R \times R D$ in model (7b), respectively. ${ }^{*},{ }^{* *}$ and ${ }^{* * *}$ indicate statistical significance at 10,5 and 1 percent, respectively. Model numbers refer to models specified in text. Sign indicates whether the coefficient is more $(>)$ or less $(<)$ than zero, and whether the $\mathrm{R}^{2}$ of the regression model featuring comprehensive income is larger $(>)$ or smaller $(<)$ than the $\mathrm{R}^{2}$ of the model incorporating net income (applies to last rows of Panels A, B, and C). Results are reported for the first and the fourth quintiles of the following variables: Size is the natural logarithm of total assets, Leverage is liabilities divided by total assets, Accruals/CFO is the absolute ratio of accounting accruals to cash flow from operations. 
As accounting choices are expected to be a function of prevailing reporting incentives, we also accessed how firm-level motivations affect results. We concentrate on four factors that drive companies' reporting quality: firm size, accounting leverage, the relative magnitude of total accruals, and the sign of net income. Results are reported in Table 9. Size is defined as the natural logarithm of total assets, leverage is the ratio of total liabilities to total assets, and the magnitude of total accruals is proxied by the ratio of absolute accounting accruals to absolute cash flow from operations (Leuz et al. 2003). We consider only non-financial companies and examine the bottom and top quartiles of the distribution of these variables or construct two sub-samples based on the sign of net income. Again, the general tenor of the results is consistent with previous findings. Other comprehensive income has some incremental relevance in equity valuation, but net income usually outperforms comprehensive income as an aggregate performance measure and we observe no contracting benefits stemming from reporting comprehensive income as it reduces conservatism and the timeliness of reporting bad news.

\section{Summary and discussion}

The IASB 'fair value' principle accentuates the importance of the balance sheet and decision relevance and reduces the importance of the conservative notion of realisation. The recent agenda project on comprehensive income potentially extends this principle by incorporating all realised and unrealised gains into one single (aggregated) comprehensive income figure. In this paper we examine value relevance and agency cost impacts using a comprehensive data set of 56,700 European firm years across sixteen countries. Continental Europe, in particular, provides a differential research setting compared to previous Anglo-Saxon embedded studies, because the code-law accounting foundations pre-IFRS 2005 were based on providing information to satisfy providers of debt capital.

Our research provides a wide ranging examination of the value relevance issue by undertaking tests from both the measurement and information perspective, by controlling for temporary components embedded in the comprehensive income figure, and by testing ability to predict operating cash flows and influence analyst price revisions. Pooled and individual country results are reported as well as results from firms using different accounting frameworks (Local GAAP, US GAAP, IFRS). We also complete the research by running Basu regressions and reporting on the asymmetric timeliness of each income measure as an indicator of conservatism.

Several consistent results are documented. Pooled regressions, using price levels and price changes as the dependent variable, reveal that net income dominates aggregated comprehensive income as a decision relevant metric. Net income also has a higher association and predictive power for future cash flows. Results are robust to controls for non-linearities, time effects, individual country regressions, the underlying type of accounting framework and several other well known individual firm characteristics. However, unrealised gains and losses on held-for-sale securities do provide incremental information over net income for investors. Moreover, other comprehensive income has incremental (though not overall) value relevance for financial analysts.

The finding that net income as a core valuation metric for the general investor dominates aggregated comprehensive income is not surprising. If markets are arrow-debreu incomplete and, comprehensive income introduces volatility through information and valuation uncertainty, then at best it is irrelevant or at worse confusing. By including temporary and volatile components such as foreign exchange fluctuations and combining them with capital increments that cannot be readily realised. The debate on whether to include capital adjustment components in income or as dirty surplus adjustments to reserves is not new. Edwards and Bell (1961) and Chambers (1966) base their income models on financial concepts of capital maintenance whilst others are based on 
maintaining operations (Revsine 1973). ${ }^{15}$ The concept of comprehensive income as presented by IFRS implicitly appears to adopt a financial concept of income and capital. However, a one-sizefits-all approach does not recognise different income concepts may be industry or firm specific. For example, price increments on operating assets are rarely income in any practical sense. Rather than increasing wealth if the firm wishes to maintain the same production process, price increases signify increased industry competitiveness, or higher future replacement costs, or greater asset efficiency in other industries. In these cases, price increments signal opportunity or competitive costs rather than real income increases.

This is not to say there is no information content in unrealized asset price increments. If the market is liquid (buying prices approximate selling prices) then there is real potential wealth increments through sale, by takeover, exchange gains, or as a signal of increased borrowing capacity. However, this requires some considerable expertise and may be beyond the average investors capabilities or willingness to invest in such information analysis. Our results show these factors are (possibly) picked up by financial analysts who glean value relevance from aggregated and unrealized asset valuations and foreign exchange increments. These firms are on general larger and more profitable with greater growth options and higher leverage. We also note that analyst coverage in our database only accounts for about four percent of firm years.

Another consistent result, and consistent with others (Barth and Clinch 1998; Dhaliwal et al. 1999), is that financial asset revaluations provide significant value relevance for prices. Again this makes pragmatic sense. Financial held-for-sale securities are usually liquid assets that can be quickly converted into financial wealth a concept well understood by most market participants. Finally, comprehensive income incorporates good news in a more timely fashion than bad news. This means comprehensive income switches the conservative attributes of income towards a more timely recognition of good news over bad news and thereby reduces the role that accounting plays in conservative agency contracting. This approach, in the extreme, could cause aberrations and bias in lending patterns and result in financial institutes being more exposed to debt capital risk.

Cornell and Landsman (2003) argue that financial reports should only convey disaggregated information. Including dirty surplus items, such as asset revaluations, mixes capital and income components and introduces noise to the income figure for the general investing public. Aggregating and including these items also negates the conservative attributes of income relied upon by debt providers of capital throughout Europe. That is, the imposition of a single aggregated comprehensive income is questionable, not only across industries but also across different countries.

Given the above, one additional agenda item for the IASB is to how to portray all aspects of income and capital components in a manner that does not make income more opaque for stakeholders. Future research could concentrate on providing greater understanding the quality of the income stream through knowledge of the transitory and permanent components. A micro approach that takes into account size, leverage and other firm characteristics such as the appropriate income determination model for particular industries should also enhance the explanatory and predictability of a firms' income. Further, capital maintenance issues are rarely discussed. There are real pragmatic issues that revolve around questions appropriate capital maintenance concepts? Finally, the impact of IFRS and income determination has a potentially larger impact on transition economies across pedagogic to pragmatic reporting issues.

\section{References}

1. American Accounting Association's Financial Accounting Standards Committee. 1997. An issues paper on comprehensive income. Accounting Horizons 11 (2):120-126.

2. Association for Investment Management and Research (AIMR). 1993. Financial Reporting in the 1990's and Beyond. Charlottesville, VA: AIMR.

\footnotetext{
${ }^{15}$ Economists such as Hicks (1946) define capital maintenance as general 'well-off-ness' which can be adapted to both situations according to circumstances.
} 
3. Ball, R., S. P. Kothari, and A. Robin. 2000. The effect of international institutional factors on properties of accounting earnings. Journal of Accounting and Economics 29 (1):1-51.

4. Ball, R., A. Robin, and G. Sadka. 2008. Is financial reporting shaped by equity markets or by debt markets? An international study of timeliness and conservatism. Review of Accounting Studies 13 (2-3):168-205.

5. Ball, R., A. Robin, and J. S. Wu. 2003. Incentives versus standards: Properties of accounting income in four East Asian countries. Journal of Accounting and Economics 36 (1-3):235-270.

6. Ball, R., and L. Shivakumar. 2005. Earnings quality in U.K. private firms: comparative loss recognition timeliness. Journal of Accounting and Economics 39 (1):83-128.

7. Barth, M. E., W. H. Beaver, and W. R. Landsman. 1996. Value-relevance of banks fair value disclosures under SFAS No. 107. The Accounting Review 71 (4):513-537.

8. 1998. Relative valuation roles of equity book value and net income as a function of financial health. Journal of Accounting and Economics 25 (1):1-34.

9. Barth, M. E., and G. Clinch. 1998. Revalued financial, tangible, and intangible assets: associations with share prices and non-market-based value estimates. Journal of Accounting Research 36 (3):199-233.

10. Basu, S. 1997. The conservatism principle and the asymmetric timeliness of earnings. Journal of Accounting and Economics 24 (1):3-37.

11. Biddle, G. C., and J.-H. Choi. 2006. Is comprehensive income useful? Journal of Contemporary Accounting and Economics 2 (1):1-32.

12. Brief, R. P., and K. V. Peasnell. 1996. Clean Surplus: A Link Between Accounting and Finance. New York and London: Garland Publishing.

13. Brimble, M., and A. Hodgson. 2005. The value relevance of comprehensive income and components for industrial firms: University of Amsterdam.

14. Burgstahler, D., C. Leuz, and L. Hail. 2006. The importance of reporting incentives: earnings management in European private and public firms. The Accounting Review 81 (5):983-1016.

15. Cahan, S. F., S. M. Courtenay, P. L. Gronewoller, and D. R. Upton. 2000. Value relevance of mandated comprehensive income disclosure. Journal of Business Finance and Accounting 27 (9-10):1273-1300.

16. Chambers, D., T. J. Linsmeier, C. Shakespeare, and T. Sougiannis. 2007. An evaluation of SFAS No. 130 comprehensive income. Review of Accounting Studies 12 (4):557-593.

17. Chambers, R. J. 1966. Accounting, Evaluation, and Economic Behavior. Englewood Cliffs, NJ: Prentice-Hall.

18. Cheng, C. S. A., J. K. Cheung, and V. Gopalakrishnan. 1993. On the usefulness of operating income, net income and comprehensive income in explaining security returns. Accounting \& Business Research 23 (91):195-203.

19. Collins, D., E. Maydew, and I. Weiss. 1997. Changes in the value-relevance of earnings and book values over the past forty years. Journal of Accounting and Economics 24 (1):39-67.

20. Cornell, B., and W. R. Landsman. 2003. Accounting valuation: is earning quality an issue? Financial Analysts Journal 59 (6):20-28.

21. Daske, H., L. Hail, C. Leuz, and R. S. Verdi. 2008. Adopting a label: Heterogeneity in the economic consequences of IFRS adoptions: Goethe University of Frankfurt.

22. Dechow, P. M. 1994. Accounting earnings and cash flows as measures of firm performance: The role of accounting accruals. Journal of Accounting and Economics 18 (1):3-42.

23. Dhaliwal, D., K. R. Subramanyam, and R. Trezevant. 1999. Is comprehensive income superior to net income as a measure of firm performance? Journal of Accounting and Economics 26 (13):43-67.

24. Djankov, S., R. La Porta, F. Lopez-de-Silanes, and A. Shleifer. 2008. The law and economics of self-dealing. Journal of Financial Economics 88 (3):430-465.

25. Easton, P. D., and T. S. Harris. 1991. Earnings as an explanatory variable for returns. Journal of Accounting Research 29 (1):19-36. 
26. Easton, P. D., T. S. Harris, and J. A. Ohlson. 1992. Aggregate accounting earnings can explain most of security returns: the case of long return intervals. Journal of Accounting and Economics $15(2-3): 119-142$.

27. Easton, P. D., and G. Sommers. 2003. Scale and the scale effect in market-based accounting research. Journal of Business Finance and Accounting 30 (1-2):25-55.

28. Edwards, E. O., and P. W. Bell. 1961. The Theory and Measurement of Business Income. Berkeley, CA: University of California Press.

29. FASB. 1997. Statement of financial accounting standards no. 130: Reporting comprehensive income. Norwalk, CT: Financial Accounting Standards Board.

30. Francis, J., and K. Schipper. 1999. Have financial statements lost their value relevance? Journal of Accounting Research 37 (2):319-352.

31. Francis, J., and R. H. Willis. 2001. An alternative test for self-selection in analysts' forecasts: Duke University.

32. Guay, W., and R. Verrecchia. 2006. Discussion of an economic framework for conservative accounting and Bushman and Piotroski. Journal of Accounting and Economics 42 (1-2):149165.

33. Hayn, C. 1995. The information content of losses. Journal of Accounting and Economics 20 (2):125-153.

34. Healy, P. M. 1985. The effect of bonus schemes on accounting decisions. Journal of Accounting and Economics 7 (1-3):85-107.

35. Hicks, J. R. 1946. Value and Capital. Oxford: The Clarendon Press.

36. Hirst, D. E., and P. E. Hopkins. 1998. Comprehensive income reporting and analysts' valuation judgments. Journal of Accounting Research 36 (3):47-75.

37. Holthausen, R. W., and R. L. Watts. 2001. The relevance of the value-relevance literature for financial accounting standard setting. Journal of Accounting and Economics 31 (1-3):3-75.

38. Hung, M. 2001. Accounting standards and value relevance of financial statements: An international analysis. Journal of Accounting and Economics 30 (3):401-420.

39. Imhoff, E. A. J., R. Lipe, and D. W. Wright. 1995. Is footnote disclosure an adequate alternative to financial statement recognition? Journal of Financial Statement Analysis 1 (1):70-81.

40. Isidro, H., J. F. O'Hanlon, and S. Young. 2004. Dirty surplus accounting flows: international evidence. Accounting and Business Research 34 (4):383-410.

41. . 2006. Dirty surplus accounting flows and valuation errors. Abacus 42 (3-4):302-344.

42. Jensen, M. C., and W. H. Meckling. 1976. Theory of the firm: Managerial behavior, agency costs and ownership structure. Journal of Financial Economics 3 (4):305-360.

43. Johnson, T. L., C. L. Reither, and R. J. Swieringa. 1995. Toward reporting comprehensive income. Accounting Horizons 9 (4):128-137.

44. Kanagaretnam, K., R. Mathieu, and M. Shehata. 2006. Usefulness of comprehensive income reporting in Canada: evidence from adoption of SFAS 130: McMaster University.

45. Kubota, K., K. Suda, and H. Takehara. 2006. Reporting of the net income plus other comprehensive income: information content test of the Japanese firms: Musashi University.

46. Lee, Y.-J., K. R. Petroni, and M. Shen. 2006. Cherry picking, disclosure quality, and comprehensive income reporting choices: the case of property-liability insurers. Contemporary Accounting Research 23 (3):655-692.

47. Leuz, C., D. Nanda, and P. D. Wysocki. 2003. Earnings management and investor protection: an international comparison. Journal of Financial Economics 69 (3):505-527.

48. Lev, B. 1989. On the usefulness of earnings and earnings research: lessons and directions from two decades of empirical research. Journal of Accounting Research 27 (3):153-192.

49. Lev, B., and P. Zarowin. 1999. The boundaries of financial reporting and how to extend them. Journal of Accounting Research 37 (2):353-385.

50. Libby, R., R. Bloomfield, and M. W. Nelson. 2002. Experimental research in financial accounting. Accounting, Organizations and Society 27 (8):775-810. 
51. Maines, L. A., and L. S. McDaniel. 2000. Effects of comprehensive-income characteristics on nonprofessional investors' judgments: the role of financial statement presentation format. The Accounting Review 75 (2):179-207.

52. Matolcsy, Z., and A. Wyatt. 2006. Capitalized intangibles and financial analysts. Accounting and Finance 46 (3):457-479.

53. May, G. O. 1937. Eating peas with your knife. Journal of Accountancy 63 (1):15-22.

54. McNichols, M. F., and P. C. O'Brien. 1997. Self-selection and analysts coverage. Journal of Accounting Research 35 (3):167-199.

55. Nobes, C., and R. Parker. 2004. Comparative International Accounting. 8th ed. London: Prentice Hall.

56. O'Hanlon, J. F., and P. F. Pope. 1999. The value-relevance of UK dirty surplus accounting flows. British Accounting Review 31 (4):459-482.

57. Ohlson, J. A. 1995. Earnings, book values, and dividends in equity valuation. Contemporary Accounting Research 11 (2):661-687.

58. - 1999. On transitory earnings. Review of Accounting Studies 4 (3-4):145-162.

59. Paton, W. A. 1934. Shortcomings of present-day financial statements. Journal of Accountancy 57 (2):108-132.

60. Revsine, L. 1973. Replacement Cost Accounting. Englewood Cliffs, NJ: Prentice-Hall.

61. Roychowdhury, S., and R. L. Watts. 2007. Asymmetric timeliness of earnings, market-to-book and conservatism in financial reporting. Journal of Accounting and Economics 44 (1-2):2-31.

62. Sanbonmatsu, D. M., F. R. Kardes, S. S. Posavac, and D. S. Houghton. 1997. Contextual influences on judgment based on limited information. Organizational Behavior and Human Decision Processes 69 (3):251-264.

63. Smith, P. A., and C. L. Reither. 1996. Comprehensive income and the effect of reporting it. Financial Analysts Journal 52 (6):14-19.

64. Stark, A. W. 1997. Linear information dynamics, dividend irrelevance, corporate valuation and the clean surplus equation. Accounting and Business Research 27 (3):219-228.

65. Tarca, A. 2006. Discussion of Isidro, O'Hanlon and Young. Abacus 42 (3-4):349-353.

66. Van Cauwenberge, P., and I. De Beelde. 2007a. A critical note on empirical comprehensive income research: Ghent University.

67. $2007 \mathrm{~b}$. On the IASB comprehensive income project: an analysis of the case for dual income display. Abacus 43 (1):1-26.

68. Vuong, Q. H. 1989. Likelihood ratio tests for model selection and non-nested hypotheses. Econometrica 57 (2):307-333.

69. Wang, Y., W. Buijink, and R. Eken. 2006. The value relevance of dirty surplus accounting flows in The Netherlands. The International Journal of Accounting 41 (4):387-405.

70. Warfield, T. D., and J. J. Wild. 1992. Accounting recognition and the relevance of earnings as an explanatory variable for returns. The Accounting Review 67 (4):821-842.

71. Watts, R. L. 1977. Corporate financial statements: a product of the market and political processes. Australian Journal of Management 2 (1):52-75.

72. 2003 . Conservatism in accounting part I: explanations and implications. Accounting Horizons 17 (3):207-221. 